\title{
Creative labour in the era of COVID-19: the case of freelancers ${ }^{1}$
}

\author{
"Manufactured risks" \\ result from human intervention \\ into the conditions of social life and into nature"
}

(Antony Giddens)

Valeria Pulignano, Markieta Domecka, Karol Muszyński, Lander Vermeerbergen, Me-Linh Riemann (Center for Sociological Research - KU Leuven)

\begin{abstract}
This working paper identifies some key areas of policy intervention for advancing socially sustainable and fair solutions for freelancers working in the creative industries, who are among those have suffered the most from the economic fallout of the COVID-19 pandemic. In particular, we focus on those who work entirely on their own account, without employees (i.e. the 'solo self-employed'), and who undertake project- or task-based work on a fixed-term basis. While demand for some services (e.g. ICT services, software development, digital communication, media, medical translation and audiobooks) has grown, due to their digital nature or essentiality in the post-COVID reality, other types of creative work have suffered due to increased competition, decreased demand, or because they were entirely put on hold due to the pandemic. National government policy measures aimed at cushioning the impact of COVID-19 on workers' livelihoods proved necessary but insufficient to guarantee long-term protection. This is because the eligibility criteria for such support measures exclude many freelancers in the creative industries. Moreover, those who have been guaranteed access to national government support are often confronted with the complexity and length of the administrative proceedings which accompany the implementation of these measures. Finally, career development and employability are vulnerable areas for freelancers due to there being a lack of (or insufficient) national funds dedicated to these areas.
\end{abstract}

\section{Introduction}

The COVID-19 pandemic is still causing tremendous human suffering, with serious and longterm implications for people's health, wellbeing and quality of life as well as for the economy, work and employment overall (Spasova et al., 2021). The global labour market scenarios are

\footnotetext{
${ }^{1}$ This research has received funding from the European Research Council (ERC) under the European Union’s Horizon 2020 research and innovation programme (Research Project ResPecTMe - Grant Agreement number 833577). We would like to thank Richard Polacek (MEI) and Dearbhal Murphy (FIA) for their valuable support at the initial stage of the research, and Claudia Mara, Milena Franke, Juliane Imbush and Ella Petrini for helping with the collection of the data on which this working paper is based.
} 
alarming. The International Labour Organization (ILO) considers the pandemic to be the most severe crisis since the Second World War. And at the core of this crisis is a loss of working hours and jobs, threatening businesses operations and employment across a range of economic sectors and industries. The ILO has estimated that during the second quarter of 2020, global working hours fell by 17.3 per cent. This is the equivalent of 495 million full-time jobs (see ILO 2020). Millions of workers are vulnerable to layoffs and income loss.

The impact on income-generating activities has been especially harsh for those employed in the creative industries. Creative industries are defined as 'those industries which have their origin in individual creativity, skill and talent and which have a potential for wealth and job creation through the generation of intellectual property' (DCMS 2015: 4). Accordingly, they include an heterogeneous cluster of activities, such as advertising and marketing; architecture; crafts; design (e.g. product, graphic and fashion); film, TV, video, radio and photography; ICT, software and computer services; publishing; museums, galleries and libraries; music, and performing and visual arts. Creative industries have been presented as an area of increasingly remarkable growth since the 1990s (Hesmondhalgh and Baker 2011). However, many of the emerging occupations in the sector feature a correspondingly increasing uncertainty and insecurity. This is particularly the case for freelancers, and trade unions have shown a high level of concern regarding the legal uncertainty linked to their status (see ETUC March 2020 and April 2020). As highlighted by the ILO, the exact legal status of freelancers is a complex issue, and varies from country to country. Although the term 'freelancer' should not be considered synonymous with 'self-employed', many freelancers do indeed have self-employed status and thus can effectively be considered to be running their own micro-enterprise. In many countries, there is no legal middle ground between employed and self-employed status, although there can be considerable areas of overlap in practice (e.g. ILO 2013; Williams and Lapeyre 2017). In our understanding, several freelancers in the creative industries undertake project or task-based work as own-account (solo) self-employed workers without employees (see also Eurofound 2017a). This is particularly the case in media, ICT, and TV and film. But fixed-term/short-term contracts are also common in the sector. For example, a 2011 survey by the International Federation of Actors (FIA) quoted in an 2014 European Commission study on " The status and working conditions of artists and cultural and creative professionals" ${ }^{2}$ had found that many dancers were working predominantly under long-term or short-term employment contracts as employees, although there was a clear trend towards an increasing use of short-term contracts. This is confirmed by our findings, which illustrate the prevalent use of fixed/short-term contracts alongside (solo) self-employment in dance. The latter can also be conceived as 'bogus' self-employed, as their ranks have been swelled due to companies dismissing their employees only to then re-hire them on a project-based capacity as self-employed workers, thereby reducing their 'fixed' costs (Lomax 2017). Several changes have underpinned the growth of freelance project work in the production and distribution of creative products. They include the integration of global markets, government policies that promote privatisation, and

\footnotetext{
2 Study available at https://eenca.com/eenca/assets/File/EENCA\%20publications/Study\%20on\%20the\%20status\%20and\%20workin g\%20conditions\%20of\%20artists\%20and\%20creative\%20professionals\%20-\%20Final\%20report.pdf
} 
the advent of digitalisation (which has led to a decrease in transport and communication costs, thereby allowing producers to access skilled labour forces at a lower cost) (MacKinlay and Smith 2008; Christopherson and Righor 2010).

Following the outbreak of the COVID-19 pandemic, some subsectors such as the performing arts were temporarily shut down due to lockdown restrictions, and are now struggling to survive. In others, such as ICT and software development, demand has remained stable, but competition has increased as a result of the crisis shock within the labour market, which has impacted pay rates and job quality for creative labour. The effects have been particularly profound on freelancers retaining an independent status, since they do not benefit from the social protections covering standard employees, or they suffer from limited protection as a result of the atypical forms of employment they are working in (this is the case for fixed/shortterm contracts). Yet although freelancers are often considered autonomous, they mostly rely on clients and projects. Moreover, some freelancers in creative industries perform work both through and outside of digital labour platforms, which involves taking on individual risk as they have to deal with revolving sources of income. Due to these risks, national governments in Europe have introduced some measures to support freelancers during the outbreak, alongside job retention schemes for salaried employees.

Against this background, this working paper considers to what extent national government measures for income and social support have helped in addressing the challenges linked to freelancing in the creative industries during the COVID-19 pandemic. Have these measures been enough to mitigate the social and economic insecurity these workers face? And what are (if any) the prospects for ensuring basic social rights and standards for creative freelancers suffering from irregular earnings and a lack of or limited access to social protection?

To address these questions, this working paper draws directly on the experiences of freelancers in creative industries during the pandemic lockdown in eight European countries (Belgium, France, Germany, Italy, the Netherlands, Poland, Sweden and the United Kingdom). We use a unique set of 100 in-depth autobiographical narrative interviews undertaken with freelancers (both solo self-employed and fixed/short-term project workers ${ }^{3}$ ) in the creative industries (i.e. audio and visual, including TV, film and dubbing; performing arts, including dancers and theatre technicians; publishing and media, including literary translators and journalists; and ICT workers and graphic designers) between March and December 2020. Within this sample, there are a substantial number of freelancers who provide work through digital labour platforms, which has helped us to shine a light on the difficulties they face within the rapidly growing gig economy. Secondary data (e.g. research reports) and 40 semi-structured expert interviews with policymakers from national governments, trade unions and employers' organisations (as well as other organisations of interest) are used to complement the qualitative interviews.

\footnotetext{
${ }^{3}$ This is the case of dancers in the performing arts who are legally fixed-term employees and, as our findings reveal, suffer from the same uncertainties and problems as self-employed freelancers due to the project nature of their work.
} 
First, we present the main challenges the outbreak of the COVID-19 pandemic has posed to freelancers within creative industries, and highlight the difficulties experienced by them. We then identify limitations to the measures implemented by national governments to support these workers, and finish by advancing several policy recommendations.

\section{COVID-19 and freelancing in the creative industries: an overview}

The biggest toll of the health disaster caused by COVID-19 has been the loss of thousands of lives, but the economic and social consequences have also been profound. According to a March 2020 global projection of the ILO, up to 25 million people could lose employment because of the pandemic. ${ }^{4}$ Many people have been left without income and searching for new jobs in a tight and volatile job market, in which atypical forms of employment, including freelancing, are increasingly gaining an established presence. According to a recent report by Eurofound (2020a: 55), 'Europe is characterized by an increasing diversity of employment forms'. What could have been considered 'new' or 'emerging' forms of work a few years ago, can thus now be seen as 'long-term' or even 'established' forms of employment.

Several global surveys have been launched to monitor freelancing work during the COVID-19 pandemic. These studies report that - similarly to North America, and more than in Asia and Australia (with data from Africa being unavailable) - Europe experienced a reduction in the demand for freelancers in 2020, with a decrease in rates and pricing. In the creative industries, the crisis has created a structural threat to the survival of many firms and freelancers. The OECD (2020) has assessed that the creative industries belong to those most affected by the crisis, with massive bankruptcies and rapid increases in unemployment. Based on a survey of more than 2,000 creative organisations and freelancers carried out by the Creative Industries Federation (CIF) between March and April 2020, a report by Oxford Economics estimates that in the UK alone, the sector has seen its gross value added fall by 25 per cent, corresponding to GBP 29 billion (USD 36.3 billion), and that one in five of those employed in the creative industry, including 119,000 full-time employees and 287,000 freelancers have lost their jobs. According to this study, the music, performing arts, and visual arts industries have been hit the hardest, with revenues and employment falling by some 54 per cent and 57 per cent, respectively, in 2020, while the film, television, video, radio, and photography industries could see revenue and employment losses of 57 per cent and 42 per cent, respectively (Oxford Economics 2020). Meanwhile, according to Eurofound (2020b), 25 per cent of freelancers in Europe have no savings at all, with 30 per cent having just enough to last three months. And compared to employees or retired workers, freelancers experience much more difficulty in making ends meet, and greater household arrears. A ProWriter survey revealed that 56 per cent of freelancers reported not having any employment elsewhere to rely on when opportunities dry up, and among that cohort, 64 per cent did not have a partner's income or family help to fall back on either (Polykoff 2020).

\footnotetext{
${ }^{4}$ During the financial crisis of 2008/2009, unemployment increased by 5.4 million in the EU (ILO).
} 
Against this grim scenario, Freelancer.com's 'Fast 50' report for the second quarter of 2020, which tracks movements concerning the top 50 fastest growing and declining jobs on the site's global marketplace, spanning Europe, North America and Asia, indicates that freelance job openings increased by over 25 per cent during the second quarter of 2020 compared to the first three months of the year, and continued to grow in the third quarter, with most openings being in creative services. How can this be explained?

The first reasons is that, as companies are struggling with economic uncertainty, they are more likely to pursue cost reduction strategies by outsourcing tasks and not hiring staff. The emergence of the 'talent economy' reveals exactly this. The 'talent economy' is defined as a technology-enabled marketplace where companies seek out the expertise of independent professionals for pre-defined and short-term business objectives (Poon 2019). The 'talent economy' system relies on the commodification of workers' skills, who must sell, retain and display their expertise as freelancing 'micro-entrepreneurs' in a competitive environment, without relying on employers for development and training (Ashford et al. 2018).

Secondly, while the demand for some types of tasks and services (e.g. those provided by live interpreters or dancers) has decreased or been entirely eliminated due to lockdown restrictions, the demand for others (e.g. medical translations and programming) has increased during the pandemic. At the same time, an increasing number of workers are likely to seek out new or additional job opportunities because of the layoffs and salary reductions we are seeing worldwide. This creates a context of enhanced competition, which has brought the costs of products down. For instance, digital platforms primarily offering creative services such as ICT and software development, translation, writing, and design, like Fiverr, Upwork and Freelancer.com, have experienced an increase in job-seeking freelancers entering the marketplace since the pandemic outbreak. This has intensified the competition within (and across) digital platforms. As a result, people who used to compete for (and relied on) 'gigs' before the pandemic have experienced a drop in their pay rates and earnings, as the price paid for a 'gig' has significantly decreased.

\section{Creative labour in the era of COVID-19}

The various difficulties faced by freelancers in creative industries in these times of pandemic include a lack of work within their professions; damaged employability and interrupted career paths; increased competition; a loss of predictability and control; and an excessive reliance on family and social networks.

\section{Lack of work within the profession}

'By February I had jobs lined up for myself until the next February so I was super happy, excited and very proud because it's rare when you start out as a freelancer that you're able to just find jobs. But then the COVID-19 crisis happened and it was all cancelled.'

Dancer, F, 36, the Netherlands
Creative industries are known for having tight working cycles, where highintensity moments are intertwined with periods of downtime or even breaks 
('from feast to famine'). However, COVID-19 generated a disruption much greater than the usual ups and downs, and this has had an adverse, if disparate, impact on various professions within the creative industries.

Some subsectors have closed down almost completely, leaving many freelancers without work. Many professionals working in film and TV, for instance, have had no work since November 2019, as this seasonal industry had been already quiet over the period Christmas and was preparing to take off again in the spring. COVID-19 has also generated a sort of 'chain' effect. To take one example, dubbing work done by voiceover actors was put on hold following the shutdown of film and TV programmes. These actors will have to wait a long time before production will be fully brought back and they will be able to return to their jobs.

Similarly, the cancellation of live performances left performing artists and technical staff without work. The whole performing arts subsector has become frozen in a 'wait-and-see' attitude, forcing freelancers to look for alternative sources of income, often on the margins (for example, dancers teaching yoga online, or graphic designers doing gigs via digital platforms) or completely outside of their profession (for example, production managers working in supermarkets, or a sound designer taking a part-time job in the postal service).

'This year already started more unstable, more unpredictable, and since the virus everything has been blocked [..] Two books that I translated that were supposed to come out have been postponed, so this is a first consequence. Second consequence: cancelled events.' Literary translator, M, 47, France
Some niches in those subsectors that are still active also experienced collapse. For instance, work for translators who translated materials for tourist companies and publishers of tourist guides was cancelled and workers were forced to find new clients in different branches of the translation market, thus increasing competition there. Literary translators, meanwhile, struggled with cancelled events, an important source of income for them.

\section{Damaged employability and interrupted career paths}

Freelancers who have been experiencing a lack of work see it as potentially detrimental to their future employability and career paths. In performing arts such as dancing, workers need to practice regularly in order to keep their bodies in shape and maintain their skills. Due to the pandemic, not only live performances but also all related events, such as workshops and meetings, were cancelled. These are crucial for creative workers to enhance their chances to network with key gatekeepers (e.g. choreographers and programme directors). Networking is essential for both performing artists (e.g. dancers) and professionals (e.g. film directors, actors, camera operators) within the TV, film and audio industries as regards visibility, training and future employability. 
'[COVID-19] has made it even harder to get a job [...] I might have to go back to school, maybe search for something more secure [...] There's literally nothing... so, yeah, I'm starting to doubt if it's worth it.'

Theatre technician, F, 29, Sweden
In many cases, because of the pandemic, performing artists were not even able to enter training rooms, which impacted their skill retention as well as their physical capacity to perform the job. This resulted in some having to

retrain to stay within the profession, and others retiring prematurely when their financial resources allowed it. In the performing arts in particular this meant that COVID-19 made some careers, which were already short, even shorter.

'Graphic design has certainly become more competitive over the last few years. It's a sign of the times, with everyone having easy access to good quality computers and the internet [...] which actually gets me thinking about changing my career or finding my niche.'

Graphic designer, F, 27, Poland

In a less dramatic fashion, other freelancers such as translators or graphic designers are also suffering from lack of work. The COVID-19 lockdowns have created difficulties within their profession and many are consequently thinking of reskilling. If the economic disruption caused by the pandemic turns out to be temporary and such workers decide to leave the sector, this is likely to create gaps in the labour market in the near future.

\section{Increased competition}

'[There are] far fewer jobs being posted, and another negative thing is the proliferation of fake professionals. There are people who now obviously don't know what to do at home and sign up to try to do something and they offer ridiculously low rates. And it's hard to make a client understand why you cost more than somebody else.'

Translator on Upwork, M, 41, Italy
Subsectors which have not experienced a complete shutdown have instead seen increased competition. This is particularly the case for freelancers working through digital platforms.

As many services went online in 2020, some freelancers such as ICT specialists and medical translators initially saw a rise in work opportunities thanks to the pandemic. However, because of the general lack of work in the profession, many freelancers went online to seek for tasks. This had the immediate effect of increasing competition and thus bringing down pay rates. On the other hand, graphic designers and translators (with the exception of medical translators) saw their job opportunities shrinking dramatically from the very early days of lockdown.

Companies started to cut off non-essential freelance work in response to the health crisis while 'waiting' for the situation to improve. Since companies are the main clients on digital platforms, their reluctance to offer new jobs and tasks had a dramatic impact on the livelihoods of platform freelancers. The latter consider their engagement with platforms as being of a long-term rather than temporary nature. Their goal is to attain a top rating on the platform in order to maximise their income, and they do this by developing their profiles, attracting clients and establishing their reputation through self-marketing strategies. This explains why they did not leave platforms as soon as they saw job offers decreasing and rates going down due to the COVID19 outbreak. They instead engaged in various coping strategies in an attempt to survive the enhanced competition. These strategies included: searching for additional sources of income, 
parallel to platform work; reducing their spending to the bare essentials; moving back to the home of their parents; and relying on savings and family resources, such as a partner's income or gifts and loans from parents and other relatives.

\section{Loss of predictability and control}

'All translators were saying: "I have nothing, no job, no new projects, I haven't had anything for months." I was in the same boat.. It was really hard to come to terms with the possibility that my pretty high income may suddenly drop to zero. I got scared. My partner is a programmer, but the future of his industry is also uncertain. When translation jobs reappeared, I tried to work as much as possible, applying for everything.'

Translator on the platform Upwork, F, 36, Poland

Within this new labour market context of a scarcity of job opportunities and increased competition within professions, freelancers experienced a loss of predictability and control over their work and careers.

Freelancers, who have generally chosen their career paths because of a desire for work autonomy, are now being forced to accept any sort of job or task they come across. This disrupts work routines, forcing them to engage in activities below their skill levels that they would normally reject, and to agree to rates, conditions and deadlines that would previously be unacceptable.

Several freelancers report that clients have used the situation of economic uncertainty and developments in the labour market as an argument for lowering fees and standards. For instance, translators, journalists and graphic designers we interviewed asserted that they were being offered much worse fees than before COVID-19, with employers citing lockdown-related difficulties as a rationale for renegotiation of previously agreed rates. In the most extreme cases, freelancers have felt forced to carry out severely underpaid or even unpaid work. For instance, young graphic designers and even IT workers we interviewed cited situations where they accepted multiple demands from clients to further adapt practically finished products out of fear that conflict would leave them without the means to live during COVID-19. Precarious situations can make freelancers desperate and thus willing to accept unfair behaviours from clients.

Freelancers cope with this situation of low bargaining power through individualised strategies of work maximisation and lowering rates, in the hope of creating some stability in their own lives and the lives of their families. However, the increasing unpredictability of the work flow and the loss of being able to be selective often lead to overworking. There was a common experience amongst the freelancers we interviewed of a feeling of loss of control over one's income and career prospects.

\section{Excessive reliance on family and social networks}


'My son [a freelancer in film and TV] isn't earning a penny now. He can't claim any money from the government. So he's one of these people that have fallen through the loopholes. Luckily his girlfriend is working so they're surviving on that money. He hasn't asked me for any help yet, but he will.'

Camera operator, M, 61, United Kingdom
Freelancers particularly vulnerable to economic shocks because of low savings were the ones who experienced a growing reliance on support from their family and social network in the form of gifts and loans. On the other hand, those who could use their savings meant they could no longer use them for their initial purpose, such as buying a first house/flat, children's education,

and care for elderly relatives. Many freelancers admitted that they were aware that the creative field is not the type of work that can make people rich and they adapted their life style accordingly, learning how to reduce their expenses and lead minimalistic lives. In the times of COVID-19, however, there is a new level of minimalism and reliance on family: one young camera operator moved back to his parents' place in order to save on rent; a dancer and mother of young children withdrew from the labour market in order to save on childcare; another dancer who lost her job and is reliant on her partner's income feels she drags her family down. These are just a few examples.

This situation not only exacerbates problems with work-life balance, it also has an impact on the way freelancers behave in their subsectors depending on whether they receive financial and material help from their family. For instance, we saw that freelancers reliant on support from their parents were more prone to accept underpaid and low-paid tasks. On the other hand, freelancers who are dependent on their partners feel they must accept any job that is available. This effects competition between professionals.

\section{National government lockdown support measures for freelancers}

National governments across Europe have introduced general support measures to protect all (solo self-employed) freelancers in the context of the COVID-19 pandemic (see Table 1 for a summary of these measures within our sample of countries).

[Table 1 about here]

Moreover, national governments have implemented tailored support measures for freelancers within diverse subsectors (see Table 2 for a summary of the measures in the selected subsectors and countries).

\section{[Table 2 about here]}

'We're a group that easily falls through the cracks. I always realise this because we're not really employed but we're also not really freelancers. We're somewhere in between. And the first immediate help packages were only for freelancers.'

Voiceover actor, M, 30, Germany
Survey respondents voiced their frustration with national measures falling short and not fully addressing the difficulties they were encountering. First, there were hardly any applications from freelancers for government support because many fell outside of the measures' scope due to their 'ambiguous' legal status

- classified as not exactly businesspeople but not exactly workers either - and also due to the 
complexity of the administrative procedures for claiming the benefits. Secondly, when the support measures were accessible, they focused primarily on financial issues. Most of the measures consisted of providing direct (through income subsidies, unemployment schemes, lump sum allowances and loans) or indirect (through changes in taxation and social insurance) financial aid for the freelancers. They also included the implementation of stimulus packages for industries and institutions. However, some key issues remained largely unaddressed by the measures, such as career development, re-training and employability, excessive reliance on aid from family and friends, increased competition and reduced predictability. Freelancers have also been experiencing a lack of control over their employment conditions and the lowering of pay rates, and have encountered difficulties in finding alternatives sources of income. These issues have also broadly remained out of the scope of government measures. Overall, we identify the following problems for freelancers regarding their ability to benefit from government support schemes:

- Lack of eligibility

- Complexity and length of administrative procedures for claiming benefits

- Insufficiency of funds to support long-term employability

- No entitlement to economic, social and labour rights

\section{Lack of eligibility}

The pandemic left many creative freelancers reliant on state support. It is common in the creative industries to perform work on the basis of various types of atypical forms of employment that are specific to the nature of the work (which is usually project-based), the space dimension of the work (which is often performed autonomously, without direct control of the employer/client), and the time dimension of the work (which is often temporary, lasting only the duration of the task/project). Because of the variety of atypical employment contracts that freelancers are hired on, many fell through holes in the safety net and were left with no support at all during the pandemic.

In most cases, governments established very rigid and 'automatic' thresholds which did not fully account for the reality of freelance work. Survey respondents reported that they were excluded from access to state support because of legal technicalities, because they had not worked long enough, or because their incomes were deemed to be too high, even if in lockdown this income collapsed to zero.

\footnotetext{
'There are support measures when you earn 60 per cent less compared to last year. [...] I would only get there if I deliberately stopped working [...] So I receive nothing [from the government]. For example, if I make 50 per cent less than last year I don't get any support. It is that simple.'

Journalist, M, 32, Belgium
}

For example, one Belgian translator was considered not eligible for state support because his income had dropped by 55 per cent and a loss of 60 per cent was 
necessary to be included in the scheme (see: Vlaams beschermingsmechanisme). ${ }^{5}$

In Germany there have been various COVID-19 emergency aid packages both at federal and state level. These subsidies in the form of lump-sum allowances (e.g. Corona Soforthilfe) and loss compensation (November/ Dezemberhilfen) are tied to a number of conditions which have been a source of controversy. At the beginning of the pandemic, freelancers could apply for a lump sum of EUR 5000. Although this measure was generally welcomed, some of our respondents did not qualify for it as their employment status was somewhat ambiguous. These workers either fell between employed and self-employed status, or were engaged in nonstandard forms of work. Other initiatives, such as the recently launched Neustarthilfe (lump sum of EUR 7,500), are restricted to those who can prove a revenue loss of at least $60 \%$ with respect to 2019 (Bundesregierung, 2021a). For some (e.g. camera operators), providing evidence of a significant revenue loss can be challenging due to the fragmented nature of their income (including seasonal fluctuations). Furthermore, some interviewees had been experiencing financial difficulties before the pandemic (e.g. debt). These interviewees worried that they could be accused of subsidy fraud by accepting COVID-19 financial support, and therefore felt discouraged from applying (sometimes spending their inheritance instead).

'The [governmental] measures, I was absolutely not eligible. I had a permanent income, but - as I said - I had a contract for a specific task, so I would not benefit from the “anti-crisis shield”.'

ICT developer, M, 21, Poland

In Poland, freelancers in creative industries often provide their work via a combination of non-standard civil law contracts which have effectively excluded them from government support. One of our respondents - an ICT developer who earned his living by selling software for sports competition - missed out on government support because the specific type of contract he had used was excluded from the range of support measures (Art. 15zq of the Act of 2 March 2020 - on special solutions related to preventing, counteracting and combating COVID-19, other infectious diseases and emergencies caused by them - provides an exhaustive list of types of contracts whose contractors are eligible for government support).

Likewise, in Sweden, some freelance dancers were denied access to unemployment benefits because they were classified as 'independent contractors', even though they had previously been accepted as members of an unemployment insurance fund. However, it is very easy to fall into the category of 'independent contractor', as it simply requires having more than three clients/employers, being a board member of a non-profit association, and undertaking promotional activities. For instance, one dancer employed on a freelance platform was denied unemployment benefit because of the number of clients she had, her role as a board member of a small dance association, and the fact that her dance group had an active website - despite being formally employed on a platform, not running a business, and having a very low income. Another dancer was denied benefits due to her side activity of teaching one hour of dance per week, which she had to invoice as sole proprietor. In addition, technical staff such as stage

\footnotetext{
5 This support measure, the Flemish Protection Mechanism for Enterprises (Agentschap Innoveren en Ondernemen), was approved on 23 October 2020 by the Flemish Government. The $60 \%$ threshold is specifically mentioned in Article 3.1.
} 
technicians were excluded from specific crisis support measures targeting the culture and arts sector, as they lack artist status. In the performing arts sector, they are among the hardest hit.

In the United Kingdom, several self-employed freelancers in the film and TV industry are paid via PAYE ('Pay As You Earn'), which excluded them from governmental aid. Those who earned a profit of more than GBP 50,000 in 2018-19, or an average trading profit of more than GBP 50,000 in 2016-17, 2017-18 and 2018-19, are not eligible. Another group excluded from government support are those who became self-employed after April 2019, as they do not have a record of making profits. In accordance with the savings threshold criteria for Universal Credit in the United Kingdom, savers with over GBP 16,000 are also currently excluded from state benefits. These are self-employed persons with tax payments saved in a personal account, young people saving for a house deposit, business start-ups who have saved to invest or are currently relying on a 'rainy day fund', and older people with retirement savings. Savers with GBP 6,000-16,000 currently have a reduced entitlement. At the moment, those excluded from Universal Credit have no access to sickness and self-isolation pay, potentially undermining the social distancing strategy.

Overall, relaxing the threshold criteria freelancers need to meet in order to get support is particularly important. Not having a clear-cut status ('not really an employee, not really a businessperson' in the words of one interviewee), which is the guarantor of access to governmental aid, has contributed to the downgrading of many freelancers' work and living conditions.

\section{Complexity and length of administrative procedures for claiming benefits}

The length and complexity of the administrative procedures for claiming benefits are often reported to be a barrier to freelancers. Even when support measures are adopted and freelancers can apply, the system is considered ambiguous, difficult to access, or simply too slow.

'I have also applied for this emergency aid
[from Berlin]. But there is still so much
uncertainty, it [what these funds can be
used for] varies from federal state to federal
state [... others, they're allowed to use it for
private things, but I'm very careful with the
money. I'm just not sure if we'll be allowed
to keep it in the end.'
Camera operator, F, 46, Germany

'I have also applied for this emergency aid [from Berlin]. But there is still so much uncertainty, it [what these funds can be used for] varies from federal state to federal state [.. others, they're allowed to use it for private things, but I'm very careful with the to keep it in the end.'

has proven to be quite inadequate for many workers, particularly in the context of the new world of remote working. ${ }^{6}$ For instance, camera operators were very cautious in terms of spending the lump-sum allowance, as they were unsure when and how they would be required to pay it back in the future. Another source of frustration were inconsistencies at the state level. Interviewees compared themselves to friends and acquaintances living in other regions of Germany, whose financial aid was tied to a different set of requirements that they perceived as preferable. Because creative work is often seasonal, prior to COVID-19 many creative workers

\footnotetext{
${ }^{6}$ Since then, the German government has acknowledged this problem for self-employed creative workers and introduced a new subsidy scheme called Neustarthilfe (part of Überbrückungshilfe III), which is more flexible with respect to the distinction between fixed and personal expenses.
} bureaucratic requirements that were tied to the financial aid. While quite a few of the participants received a lump sum of GBP 5,000 in spring 2020, there was widespread confusion about how these grants were supposed to be spent (and paid back). The strict distinction between fixed costs and private expenses 
in TV/film experienced quiet winter months and then made up for their lack of revenue during this period with very busy summers. For these workers, the so-called 'November/Dezemberhilfen' government subsidies for freelancers were less than ideal. These subsidies were strictly tied to what applicants earned in November and December 2019, reimbursing them up to 75\%: a calculation that resulted in sums that were often insufficient to cover basic expenses.

Several freelancers in Italy struggled with applying for funding due to technical reasons. The applications had to be filed with the Italian Social Security Institution (INPS) on their website. However, the website repeatedly crashed in April 2020 because of the high number of users, and therefore many applicants were not able to log in to apply for help. Even though the problem was eventually solved, it slowed down the process of distribution of crisis support.

With the Polish Social Security Institution similarly being flooded with applications for unemployment benefits and other support measures, several of our interviewees in this country were uncertain how, or even whether, their applications would be considered. This had an impact on their career plans. For instance, one of our respondents, who is an ICT freelancer doing online gigs, had to wait for four months to receive special unemployment benefits, forcing him to overwork.

'I think I applied in August, or at the end of July and then they took eight months to process my application, and then I was rejected.'

Dancer, 33, F, Sweden
In Sweden as well, the processing of applications for unemployment funds has often proved to be lengthy, especially for creative workers, who often have multiple different contracts with mixed contractual statuses: some projects are undertaken as fixed/short-term employees, and some as selfemployed workers. Concretely, the long administrative procedures meant that freelancers both fixed/short-term and self-employed - had to save in the eventuality of unemployment, even if officially they had access to unemployment insurance funds.

It is clear that the implementation of support measures has not been efficient enough. It is necessary to ensure that information about the aid available to freelancers, as well as about how to access it, is made clear and understandable.

\section{Insufficiency of funds to support long-term employability}

Some professions have experienced a dire situation due to lockdown. And while support measures have been sufficient to help them survive the economic consequences of the pandemic, they have not enabled them to deal with the problem of maintaining long-term employability. The funds have not been enough to cover the costs of maintaining skills or reskilling, and thereby finding a new job.

This is well represented by the case of dancers in the Netherlands and Sweden, who need to constantly practice to retain the same level of skill and physical capability of the body in order to be able to work at length in their profession. Funds are sometimes enough for them to live off, but they are not sufficient to either cover the costs of continuous training within the profession, or to change occupation to a different one. Respondents highlighted that they have found themselves stuck in a dead-end scenario, where the chances of going back to their 
previous occupation are dependent upon their individual efforts to maintain their skills through use of their own private resources (savings, loans from family and friends, etc.), but that such resources are not enough to enable reskilling.

One of our respondents in the Netherlands - a dancer who benefits from government funds found herself having to practice to keep in shape in a small apartment in Amsterdam, with two children who were learning remotely from home. Given how difficult it is to exercise in such an environment, with lockdown negatively impacting skills and shortening an already short career, the government funds are not sufficient to give dancers the opportunity to reskill.

In Sweden, permanent theatre technicians in the performing arts sector who have the right to bargain were able to negotiate a reskilling scheme. However, short-term employees and selfemployed workers in the same occupation are not covered by such schemes. Some interviewees mentioned applying for university courses (which are free) if faced with unemployment, saying that this way they could live off student grants and loans.

\section{Lack of or limited entitlement to economic, social and labour rights}

'COVID-19 has really highlighted the lack of rights that film and TV workers have and the government doesn't really know what to do with us either.'

Graphic designer, F, 31, United Kingdom
Freelancers were left out of national governments’ aid measures because policymakers overlooked the 'reality of work' of thousands of them suffering poor access to economic, social and labour rights.

For example, a Polish translator working through a digital platform highlighted that even though she is, in theory, covered by the regulation on the hourly minimum wage (applicable to all selfemployed), this regulation is not effectively implemented due to competitive pressures that have been exacerbated during the COVID-19 outbreak. No specific regulation aimed at protecting a rising share of creative freelancers working via platforms has been adopted or is planned.

Furthermore, in Sweden, agreements about future work opportunities for creative freelancers are often informal, and contracts (if there is one) are only signed at the last minute or even after the project has already begun. Because many of the crisis grants offered to creative workers in Sweden require proof of termination, the workers were, de facto, unable to access grants. In this way, crisis measures did not reflect the complex reality of creative work where workers shape their strategies on the basis of tacit understanding and informal cooperation with their institutions.

Overall, the problems we identified (i.e. eligibility, complex administrative procedures, the insufficiency of funds to support long-term employability, and a lack of or limited entitlement to economic, social and labour rights) have limited freelancers' access to national support measures based on several criteria, which we identify as income, loss in turnover/revenue, occupation, legal form of employment, and date of commencement of activities (see Table 3 for an illustration of these criteria across countries).

[Table 3 about here] 


\section{Policy recommendations}

In order to deal with the deficiencies in national governments' support measures, we suggest adopting the following changes:

\section{Inclusion of creative freelancers in collective bargaining and policy consultations}

In many countries, solutions have been insufficient for freelancers because of their effective exclusion from both collective bargaining and policy consultations. Whereas employers and employees in traditional sectors are able to adopt solutions at a national and sectoral level through means of collective bargaining and are well represented in the policy cycle through their representatives, this is not always the case for the self-employed working for a sole employer on a project-based capacity because of their employment status, which is somewhere in between 'businesspeople' and 'subordinate workers'. This is often also the case for fixed/short-term employees hired on projects who suffer from limited access to collective bargaining and less interest from trade unions. Although other relevant professional organisations may exist, they need appropriate representation structures for bargaining. Therefore, it is necessary to think about solutions that can ensure that freelancers have a voice through the creation of representation structures, both with respect to the employers (several of the self-employed professionals we interviewed are in a position of engaging in 'predominantly personal work' or their own labour) ${ }^{7}$, and as regards granting them a presence in the policy cycle and in the creation of public policies.

\section{Mitigating the difficulties in accessing financial support measures: universal protection for freelancers}

Universal national protection measures and (potentially) tax and social insurance changes to guarantee long-term support remain critical for freelancers. National protection measures should be universal, adequate and easily accessible so as to offer a real protection against the shocks which can affect labour markets, and which are usually associated with ongoing economic difficulties. Since it cannot be expected that creative industries will all bounce back equally quickly to their previous shape, it is also important to foresee measures able to support those most in need as we come out of the crisis. This could include universal and generous basic income support, healthcare and a basic pension. Moreover, unemployment schemes should be introduced in order to help those who lost their entire income or a substantial part of it. Expanding social insurance for freelancers by incorporating social contributions into general taxation may reduce companies' incentives to resort to freelancers instead of paid employees, as is mainly the case with digital platforms.

\section{Reclassifying the legal status of (solo self-employed) freelancers}

Most freelancers in the creative industries are solo self-employed workers, working on various projects. Outsourcing work and framing it into 'projects' are often employer strategies aimed

\footnotetext{
${ }^{7}$ See the European pre-consultation on this issue ('Collective bargaining agreement for self-employed - scope of application EU competition rules') at https:/ec.europa.eu/info/law/better-regulation/have-yoursay/initiatives/12483-Collective-bargaining-agreements-for-self-employed-scope-of-application-EUcompetition-rules
} 
at reducing costs by making their employees self-employed and thus avoiding all social costs that a regular employment relationship implies - for example, to avoid the necessity of paying the minimum wage, to circumvent working time provisions, or to bypass dismissal procedures. Such strategies have proven to be particularly harmful in the face of the economic collapse that followed the health crisis, which has left freelancers, often working for a sole employer, at the mercy of policymakers implementing (or not) extraordinary solutions. However, many of these so-called freelancers should legally be treated as subordinate workers in their respective national jurisdictions. Because such a reclassification depends on legal tests used by courts to define who is 'subordinate', we advocate here that the concept of 'own labour' be used to extend social security and labour rights beyond the narrow category of subordinate employment. This could improve the working conditions and bargaining power of freelancers vis-à-vis their de facto employers in general, and not just in the COVID-19 context.

\section{Mitigating the increased competition: product market regulation in sectors}

Businesses have started to restructure their operations in order to cushion the impact of losses in corporate profit caused by the pandemic. Restructuring can also include outsourcing, as is the case for digital advertising agencies and software developers, which have been outsourcing work to independent contractors during the pandemic. Similarly, publishing and media companies have initiated restructuring and been shifting toward a greater use of online freelancers for different jobs ('digital outsourcing'), such as design and translation. Therefore, regulation by law and the setting of institutional structures able to safeguard social conditions in the labour market would help to cushion the effects of these attempts by enterprises to survive the pandemic. For instance, publishing and media companies, whose operations often depend on grants or co-financing from the public sector, could be required to utilise only the services of professional translators. Regulation could also increase the entry level for online platforms and effectively prevent them from using aggressive cost-cutting strategies against their competitors.

\section{Mitigating the loss of predictability and control over employment conditions and working time: setting minimum standards}

The lockdown led to a substantial decrease in demand and increase in competition between freelancers, forcing them to accept exceptionally low rates and unfavourable working conditions. Introducing minimum standards regarding employment, hours and wages would be an essential first step for establishing fair working conditions in the creative industries, both offline and digital. In this regard, the French Labour Code is a good example to follow. The French Labour Code includes a number of rebuttable presumptions classifying as dependent workers specific freelancing professions that typically struggle to prove their subordinate status: for example, journalists (Article L7112-1), performing artists (L7121-3), and models (L71233). This limits the occurrence of such abuses as workers being forced to engage in low- or unpaid work: for example, situations where freelancers are forced to do additional tasks for their clients. Moreover, minimum standards can enable the setting up of social safety nets for freelancers and therefore help to limit their reliance on family resources, one of the most problematic outcomes of the COVID-19 pandemic for this kind of worker. They may also help to close the gap in social provisions between the self-employed and employees. 


\section{Mitigating the increased reliance on family: support for households}

Although they may be considered as 'independent', in reality freelancers strongly depend on work from clients. COVID-19 hit the income sources and savings of a large number of the selfemployed very hard. Loss of income has contributed to an increase in dependency on partners, family and close friends, often putting whole households in an insecure position. It is important to ensure that vulnerable households who have lost most or all of their income in the current crisis can make ends meet. This can reduce the vulnerability of freelancers in households with small to modest incomes/savings, and where freelancers themselves are the main earners. Therefore, creating support structures for freelancers with childcare responsibilities and additional family needs, or who are in self-isolation because of COVID-19, is key.

Mitigating the career development and employability problems among creative professionals

The COVID-19 pandemic has led to many freelancers in the creative professions having to put their careers on hold. We must recognise the impact this will have on the social mobility of workers, their employability and their future career development. Introducing measures that will provide creative workers who want to stay in their professions with support is necessary, particularly because if they reskill too quickly, society risks losing their original skills altogether. Such necessary measures include not only temporary income support schemes, but also long-term opportunities for freelancers to improve and update their skills in preparation for the aftermath of the COVID-19 pandemic, such as continuous training and access to the required infrastructure (e.g. rooms for rehearsal, training, etc.). Finally, for those who would like to transition into another sector, it is necessary to expand the provision of professional training that will enable reskilling. 


\section{References}

Agentschap voor Innoveren en Ondernemen (2020a) Wie heeft recht op het Vlaams beschermingsmechanisme, beschermingsmechanisme/wie-heeft-recht-op-het-vlaams

Ashford, S.J., Caza, B.B., \& Reid, E.M. (2018) From surviving to thriving in the gig economy: A research agenda for individuals in the new world of work, Research in Organizational Behavior 38, 23-41.

Bundesministerium fuer Arbeit und Soziales (2021) Informationen zu Corona: Grundsicherung. https://www.bmas.de/DE/Schwerpunkte/Informationen-

Corona/Grundsicherung/grundsicherung.html;jsessionid=A04324879E532F6A6CA9E2D08CA 60F76.delivery2-replication

Bundesregierung (2021a) Die Maßnahmen im Überblick: Hilfen für Künstler und Kreative. https://www.bundesregierung.de/breg-de/themen/coronavirus/hilfen-fuer-kuenstler-und-kreative-1732438

Bundesregierung (2021b) Konjunkturprogramm fuer Kultur und Medienbereich: Neustart Kultur. https://www.bundesregierung.de/breg-de/bundesregierung/staatsministerin-fuer-kultur-undmedien/neustart-kultur-startet-1775272

Bundesregierung (2021c) Wirtschaftshilfen in der Corona-Pandemie: Unterstützung für Selbstständige und Unternehmen. https://www.bundesregierung.de/breg-de/themen/coronavirus/infounternehmen-selbstaendige-1735010

Christopherson S., Righor, N. (2010) The Creative Economy as "Big Business": Evaluating State Strategies to Lure Filmmakers, Journal of Planning Education and Research, 29 (3), 336-352.

DCMS (2015) Creative Industries Economic Estimates January 2015, London. https://assets.publishing.service.gov.uk/government/uploads/system/uploads/attachment_data/ file/394668/Creative_Industries_Economic_Estimates_-_January_2015.pdf

ETUC (March 2020) Covid-19 Watch ETUC Briefing Note: National measures to protect nonstandard workers including workers in the platform economy. https://www.etuc.org/sites/default/files/publication/file/2020-

04/National\%20measures\%20to\%20protect.pdf

ETUC (April 2020) Covid-19 Watch ETUC Briefing Note: National measures to protect selfemployed workers. https://www.etuc.org/sites/default/files/publication/file/202004/20200424_Covid-19\%20Briefing\%20self-employed\%20workers.pdf

Eurofound (2017) Aspects of non-standard employment in Europe, Dublin.

Eurofound (2020a) New Forms of Employment - 2020 Update, Dublin.

Eurofound (2020b) Living, working and COVID-19: First findings - April 2020, Luxembourg: Publications Office of the European Union, https://www.eurofound.europa.eu/topic/covid-19

$\begin{array}{lllll}\text { Freelancer.com. } & \text { (2020) } & \text { Fast } & 50 & \text { Report }\end{array}$ https://s3.amazonaws.com/press.freelancer.com/Media\%20Release_FLN_Fast\%2050\%20Q2 \%202020_US.pdf 
Hesmondhalgh D. and Baker S. (2011) Creative Labour. Media Work in three Cultural Industries, London, Routledge.

ILO (2013) Regulating the Employment Relationship in Europe: A guide to Recommendation No. 198. Geneva, International Labour Office.

ILO (2020) ILO Monitor: COVID-19 and the world of work. Sixth edition. Geneva: ILO. https://www.ilo.org/wcmsp5/groups/public/---dgreports/---

dcomm/documents/briefingnote/wcms 755910.pdf

Lomax R. (2017) Self-employment: A view from the inside, Transfer, 23 (3), 367-369.

McKinlay A. and Smith C. (2008) Creative Labour. Working in the Creative Industries, London, Palgrave MacMillan.

OECD (2020) Culture shock: COVID-19 and the cultural and creative sectors. http://www.oecd.org/coronavirus/policy-responses/culture-shock-covid-19-and-the-cultural-andcreative-sectors-08da9e0e/

Oxford Economics (2020) The projected economic impact of Covid-19 on the UK creative industries $\quad$ https://www.creativeindustriesfederation.com/sites/default/files/inlineimages/20200716_OE_Slides_new\%20ACE\%20data\%20-\%20Clean\%20\%20with\%20NEMO\%20caveat.pdf

Poon T.S.C. (2019). Independent workers: Growth trends, categories, and employee relations implications in the emerging gig economy. Employee Responsibilities and Rights Journal 31(1), 63-69.

Polykoff D. (2020) This is how freelancers are managing unique COVID-19 challenges https://prowriter.co/blog/Covid-19-challenges/

Spasova S., Ghailani D., Sabato S., Coster S., Fronteddu B. and Vanhercke B. (2021) Nonstandard workers and the self-employed in the EU: social protection during the Covid-19 pandemic, Report 02, Brussels: ETUI.

All links were checked on 08.03.2021 
Table 1. General support measures for all freelancers adopted by national governments

\begin{tabular}{|c|c|c|c|}
\hline Country & Temporary support schemes & One-off support schemes & Tax and social insurance \\
\hline Belgium & $\begin{array}{l}\text { Income subsidy schemes: no data } \\
\text { Unemployment schemes: support for the self-employed } \\
\text { forced to stop their activity due to COVID-19; between } \\
\text { EUR 1,291.69 (without a dependent family member) and } \\
\text { EUR 1,614.10 (with at least one dependent family member) } \\
\text { per month; amount doubled in October/November/January }\end{array}$ & $\begin{array}{l}\text { Lump-sum allowances: various } \\
\text { regional instruments } \\
\text { Loans: various regional } \\
\text { instruments }\end{array}$ & $\begin{array}{l}\text { Social insurance: expansion of sickness } \\
\text { benefit in case of COVID-19 (from first day } \\
\text { onwards instead of from eighth day) } \\
\text { Tax reductions: no social security payments } \\
\text { for freelancers without income } \\
\begin{array}{l}\text { Deferral of taxes and social security } \\
\text { contributions: introduced }\end{array}\end{array}$ \\
\hline France & $\begin{array}{l}\text { Income subsidy schemes: solidarity funds for freelancers } \\
\text { who suffer a loss of income of 50\% (available from March } \\
2020 \text { onwards) } \\
\text { Unemployment schemes: partial unemployment scheme; } \\
\text { eligibility period for unemployment benefit extended for the } \\
\text { duration of the confinement; adjustments to the } \\
\text { unemployment insurance rules for performing artists and } \\
\text { technicians }\end{array}$ & $\begin{array}{l}\text { Lump-sum allowances: up to EUR } \\
\text { 1,500 per month to compensate for } \\
\text { the loss of activities and income } \\
\text { Loans: bank guarantees }\end{array}$ & $\begin{array}{l}\text { Social insurance: no data } \\
\text { Tax reductions: direct tax reductions } \\
\text { Deferral of taxes and social security } \\
\text { contributions: introduced for the self- } \\
\text { employed in specific sectors, including the } \\
\text { culture and events sectors }\end{array}$ \\
\hline Germany & $\begin{array}{l}\text { Income subsidy schemes: access to basic income support } \\
\text { ('Grundsicherung') eased for jobseekers (especially for self- } \\
\text { employed workers); contributions towards fixed costs } \\
\text { ('Überbrückungshilfe III') } \\
\text { Unemployment schemes: unemployment benefit extended } \\
\text { by three months for all recipients whose entitlements ended } \\
\text { between May and December }\end{array}$ & $\begin{array}{l}\text { Lump sum allowances: one-time } \\
\text { emergency aid payment (max. EUR } \\
\text { 5,000) to cover the period from } \\
\text { January to June 2021; lump sum } \\
\text { covering up to 75\% of pandemic- } \\
\text { related income loss ('November- } \\
\text { Dezemberhilfe'); lump sum } \\
\text { allowance of up to EUR 7,500 from } \\
\text { January to June 2021 (with } \\
\text { prerequisite of } 60 \% \text { revenue loss } \\
\text { with respect to 2019) } \\
\text { (Neustarthilfe, part of } \\
\text { Überbrückungshilfe III) } \\
\\
\text { Loans: subsidised emergency loans }\end{array}$ & $\begin{array}{l}\text { Social insurance: option of payment } \\
\text { deferral in case of economic difficulties } \\
\text { Tax reductions: direct tax reductions } \\
\text { Deferral of taxes and social security } \\
\text { contributions: facilitation of such deferrals }\end{array}$ \\
\hline
\end{tabular}




\begin{tabular}{|c|c|c|c|}
\hline Italy & $\begin{array}{l}\text { Income subsidy schemes: various income subsidy schemes } \\
\text { ranging from EUR } 600 \text { to 1,000, with coverage differing } \\
\text { between professions and over time depending on lockdown } \\
\text { restrictions: Decreto-Legge } 17 \text { March 2020, n. } 18 \text { (the so- } \\
\text { called 'Decreto Cura Italia'), Decreto Legge } 19 \text { May 2020, n. } \\
34 \text { ('Decreto Rilancio'); Decreto Legge } 28 \text { October 2020, } \\
\text { n.137, and } 9 \text { November 2020, n.149 ('Decreto Ristori' and } \\
\text { 'Ristori-bis'); some creative activities included, but IT and } \\
\text { graphic designers excluded; eligibility primarily based upon } \\
\text { proof of income loss }\end{array}$ & $\begin{array}{l}\text { Lump-sum allowances: various } \\
\text { instruments depending on the } \\
\text { month, type of work activity and } \\
\text { income loss } \\
\text { Loans: suspension of repayment of } \\
\text { public loans; extended guarantees }\end{array}$ & $\begin{array}{l}\text { Social insurance: maternity and paternity } \\
\text { allowances given even when contributions } \\
\text { are suspended } \\
\text { Tax reductions: no data } \\
\text { Deferral of taxes and social security } \\
\text { contributions: deferral of taxes for } \\
\text { professionals without employees, with } \\
\text { revenues or fees not exceeding EUR } \\
\text { 400,000; overhaul of the social protection } \\
\text { scheme for the self-employed envisioned in } \\
\text { the Budget Law } 2021\end{array}$ \\
\hline Netherlands & $\begin{array}{l}\text { Income subsidy schemes: temporary bridging measure for } \\
\text { self-employed professionals: Decree of } 17 \text { April 2020, } \\
\text { which lays down temporary rules on assistance to self- } \\
\text { employed persons financially affected by the consequences } \\
\text { of the COVID-19 crisis ('TOZO') (maximum income } \\
\text { threshold: EUR 1,500 net) } \\
\text { Unemployment schemes: no data }\end{array}$ & $\begin{array}{l}\text { Lump-sum allowances: no data } \\
\text { Loans: working capital loan } \\
\text { (maximum EUR 10,157) at a } \\
\text { favourable interest rate; } \\
\text { government acts as a guarantor for } \\
75-95 \% \text { of loans (of smaller } \\
\text { amounts) to freelancers }\end{array}$ & $\begin{array}{l}\text { Social insurance: no data } \\
\text { Tax reductions: compensation of fixed costs } \\
\text { for freelancers who lost } 30 \% \text { of their } \\
\text { turnover } \\
\text { Deferral of taxes and social security } \\
\text { contributions: delay of tax payments for } \\
\text { three months }\end{array}$ \\
\hline Poland & $\begin{array}{l}\text { Income subsidy schemes: subsidies for costs of business } \\
\text { operations for a loss of turnover of at least } 30 \% \text {; additional } \\
\text { subsidy amounting to } 80 \% \text { of minimum wage ('świadczenie } \\
\text { postojowe') in case of revenue loss of at least } 15 \% \text { for self- } \\
\text { employed and civil law contractors (for three months } \\
\text { initially, followed by various additional subsidies for } \\
\text { professions affected by lockdown:'Tarcza Antykryzysowa } \\
\text { 1.0, 5.0, 6.0, 7.0') }\end{array}$ & $\begin{array}{l}\text { Lump-sum allowances: non- } \\
\text { refundable three-month grants for } \\
\text { entrepreneurs; two non-refundable } \\
\text { loans for entrepreneurs (PLN 5,000 } \\
\text { each); working capital subsidies of } \\
\text { up to PLN 23,500 } \\
\text { Loans: extended guarantees for } \\
\text { credit; loans at a favourable rate }\end{array}$ & $\begin{array}{l}\text { Social insurance: additional benefits for } \\
\text { persons taking care of children due to } \\
\text { closing of childcare facilities } \\
\text { Tax reductions: possible cancellation of } \\
\text { social security contributions } \\
\text { Deferral of taxes and social security } \\
\text { contributions: postponement of social } \\
\text { security contributions }\end{array}$ \\
\hline Sweden & $\begin{array}{l}\text { Income subsidy schemes: direct support for loss of turnover } \\
\text { of at least } 30 \%\end{array}$ & $\begin{array}{l}\text { Lump-sum allowances: no data } \\
\text { Loans: bank guarantees }\end{array}$ & $\begin{array}{l}\text { Social insurance: self-employed entitled to } \\
\text { receive standard sick pay for } 14 \text { days }\end{array}$ \\
\hline
\end{tabular}




\begin{tabular}{|c|c|c|c|}
\hline & $\begin{array}{l}\text { Unemployment schemes: more generous unemployment } \\
\text { benefits, with minimum-contribution requirements waived }\end{array}$ & & $\begin{array}{l}\text { Tax reductions: reduction of individual } \\
\text { contributions for self-employed } \\
\text { Deferral of taxes and social security } \\
\text { contributions: deferred VAT payments }\end{array}$ \\
\hline $\begin{array}{l}\text { United } \\
\text { Kingdom }\end{array}$ & $\begin{array}{l}\text { Income subsidy schemes: Self-employment Income Support } \\
\text { Scheme (SEISS): first grant: } 80 \% \text { of average monthly } \\
\text { trading profits, capped at GBP 7,500; second taxable grant: } \\
70 \% \text { of average monthly trading profits, paid out in a single } \\
\text { instalment covering three months' worth of profits, capped } \\
\text { at GBP 6,570; SEISS scheme extended to spring } 2021\end{array}$ & $\begin{array}{l}\text { Lump-sum allowances: one-off } \\
\text { cash grant of GBP 10,000 from } \\
\text { local council } \\
\text { Loans: scheme helps small and } \\
\text { medium-sized businesses to borrow } \\
\text { between GBP 2,000 and up to 25\% } \\
\text { of their turnover; maximum loan } \\
\text { available is GBP 50,000 }\end{array}$ & $\begin{array}{l}\text { Social insurance: statutory sick pay paid } \\
\text { from first day } \\
\text { Tax reductions: no } \\
\text { Deferral of taxes and social contributions: } \\
\text { deferred VAT payments }\end{array}$ \\
\hline
\end{tabular}

Source: own elaboration

\section{Table 2. Support measures within specific subsectors adopted by national governments}

\begin{tabular}{|c|c|}
\hline Subsector & Country measures \\
\hline $\begin{array}{l}\text { Publishing and media } \\
\text { (literally translators; journalists, } \\
\text { etc.) }\end{array}$ & $\begin{array}{l}\text { Belgium: cultural activity fund for organisations to finance initiatives available to the public; an increase of the budget for } \\
\text { projects in research journalism; various initiatives at a regional level: corona funds for precarious stakeholders of up to EUR } \\
\text { 1,500 for one-person businesses or employees that could not access the federal or regional compensation measures; EUR } 100 \\
\text { for presentations that were normally subsidised but now cancelled in Flanders } \\
\text { France: subsidies by the Centre National du Livre for literary translators and authors; for other freelancers only general } \\
\text { measures } \\
\text { Sweden: crisis grants for loss of income or business revenue distributed in spring/summer } 2020 \text { from the Writers Fund; extra } \\
\text { working grants of SEK 50,000 for writers, cultural critics and translators }\end{array}$ \\
\hline $\begin{array}{l}\text { Audio and Video } \\
\text { (TV/film professionals, voiceover } \\
\text { artists, etc.) }\end{array}$ & $\begin{array}{l}\text { Germany: subsidy programme to support (among other initiatives) TV/film productions that were interrupted due to COVID- } \\
19 \text { (Neustart Kultur); subsidies for artists' social insurance and the option of payment deferrals in case of financial hardship; } \\
\text { large-scale scholarship programmes for creative workers at a regional level } \\
\text { United Kingdom: support for productions: GBP } 500 \text { million in direct compensation for the losses caused by COVID-19 } \\
\text { available for the film/TV industry to restart production in the UK (Film and TV Production Restart Scheme); possibility to } \\
\text { apply for GBP } 2 \text { million of funding for independent British productions interrupted by COVID-19 }\end{array}$ \\
\hline $\begin{array}{l}\text { Performing arts } \\
\text { (dancers, theatre technicians, etc.) }\end{array}$ & Netherlands: none - only general measures for all freelancers \\
\hline
\end{tabular}




\begin{tabular}{|l|l|}
\hline & $\begin{array}{l}\text { Sweden: crisis grants available for all professional artists from the Arts Grants Committee: crisis grant one: for proven lost } \\
\text { incomes due to cancellations, SEK 15,000, SEK 30,000, or SEK 50,000; crisis grant two: to cover the needs of professional } \\
\text { artistic practice; SEK 50,200; crisis grant three: from the Arts Council, for dance groups and companies to compensate for } \\
\text { cancelled performances or shows, or for 'special economic needs'; extra government funding for the Dance Alliance }\end{array}$ \\
\hline ICT and graphic design & $\begin{array}{l}\text { Italy: none - only general measures for all freelancers } \\
\text { Netherlands: none - only general measures for all freelancers } \\
\text { Poland: none - only general measures for all freelancers }\end{array}$ \\
\hline
\end{tabular}

Source: own elaboration

Table 3: Different country criteria for freelancers to access support measures

\begin{tabular}{|l|l|l|l|l|l|l|l|l|}
\hline & $\mathbf{B E}$ & $\mathbf{F R}$ & $\mathbf{D E}$ & $\mathbf{I T}$ & $\mathbf{N L}$ & $\mathbf{P L}$ & $\mathbf{S E}$ & $\mathbf{U K}$ \\
\hline $\begin{array}{l}\text { Income criterion (freelancers } \\
\text { earning more than threshold } \\
\text { excluded) }\end{array}$ & $\mathbf{Y}$ & $\mathbf{Y}$ & $\mathbf{N}$ & $\mathbf{Y}$ & $\mathbf{Y}$ & $\mathbf{Y}$ & $\mathbf{N}$ & $\mathbf{Y}$ \\
\hline $\begin{array}{l}\text { Loss in turnover/revenue } \\
\text { criterion }\end{array}$ & $\mathbf{Y}$ & $\mathbf{Y}$ & $\mathbf{Y}$ & $\mathbf{Y}$ & $\mathbf{Y}$ & $\mathbf{Y}$ & $\mathbf{Y}$ & $\mathbf{Y}$ \\
\hline $\begin{array}{l}\text { Main occupation criterion } \\
\text { (freelancers self-employed as side } \\
\text { job or with not enough working } \\
\text { hours excluded) }\end{array}$ & $\mathbf{Y}$ & $\mathbf{Y}$ & $\mathbf{N}$ & $\mathbf{N}$ & $\mathbf{Y}$ & $\mathbf{N}$ & $\mathbf{N}$ & $\mathbf{Y}$ \\
\hline $\begin{array}{l}\text { Legal form criterion (freelancers } \\
\text { conducting activity in a specific } \\
\text { legal form excluded) }\end{array}$ & $\mathbf{Y}$ & $\mathbf{N}$ & $\mathbf{N}$ & $\mathbf{N}$ & $\mathbf{Y}$ & $\mathbf{Y}$ & $\mathbf{N}$ & $\mathbf{Y}$ \\
\hline $\begin{array}{l}\text { Commencement of activities } \\
\text { criterion (freelancers who started } \\
\text { after specific date excluded) }\end{array}$ & $\mathbf{Y}$ & $\mathbf{Y}$ & $\mathbf{N}$ & $\mathbf{N}$ & $\mathbf{Y}$ & $\mathbf{Y}$ & $\mathbf{Y}$ & $\mathbf{Y}$ \\
\hline
\end{tabular}

$\mathrm{Y}$ : introduce

Source: own elaboration

${ }^{8}$ Requirements of a certain level of revenue for 2019, in practice excluding new freelancers. 


\section{Methodological Appendix}

Table 1 : Classification of respondents within creative industries

\begin{tabular}{|l|l|l|l|l|l|l|l|}
\hline $\begin{array}{l}\text { Creative } \\
\text { industries }\end{array}$ & Country & Female & Male & $<30$ & $30-50$ & $>50$ & $\sum \mathbf{1 0 0}$ \\
\hline Video and audio & $\begin{array}{l}\text { Germany } \\
\text { UK }\end{array}$ & 18 & 16 & 3 & 24 & 7 & 34 \\
\hline Performing arts & $\begin{array}{l}\text { Netherlands } \\
\text { Sweden }\end{array}$ & 16 & 9 & 6 & 18 & 1 & 25 \\
\hline $\begin{array}{l}\text { Publishing and } \\
\text { media }\end{array}$ & $\begin{array}{l}\text { Belgium } \\
\text { France } \\
\text { Sweden }\end{array}$ & 15 & 12 & 2 & 21 & 4 & 27 \\
\hline $\begin{array}{l}\text { ICT and graphic } \\
\text { design }\end{array}$ & $\begin{array}{l}\text { Italy } \\
\text { Netherlands } \\
\text { Poland }\end{array}$ & 2 & 12 & 6 & 7 & 1 & 14 \\
\hline
\end{tabular}

